\title{
Effect of immediate dentin sealing and temporary cement removal on bond strength of resin cements to dentin
}

\author{
Efeito do selamento dentinário imediato e da remoção do cimento provisório na resistência de união \\ de cimentos resinosos à dentina

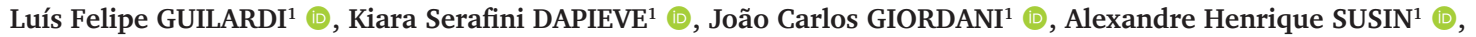 \\ Luiz Felipe VALANDRO ${ }^{1}$ (D), Marília Pivetta RIPPE ${ }^{1}$ [i] \\ 1 - Universidade Federal de Santa Maria, Department of Restorative Dentistry, Santa Maria, RS, Brazil.
}

\begin{abstract}
Objective: To evaluate the influence of immediate dentin sealing (IDS) and mechanical methods for removing the temporary cement on the bond strength between dentin and resin cements. Material and Methods: Bovine incisors were ground until dentin exposure and divided according to two factors: "dentin surface treatment" - cleaning with manual dental excavator (DE), with Robinson bristle brush and pumice paste (PP) or IDS application with Single Bond 2 (IDS/SB + PP) or Single Bond Universal (IDS/SBU+PP) plus cleaning with PP; and "resin cement" - Self-adhesive (RelyX U200) or conventional cement with self-etching adhesive (Multilink Automix). Simulating provisional restoration, acrylic resin plates were cemented onto the dentin surface (with or without IDS) with a non-eugenol temporary cement, and stored in distilled water $\left(37^{\circ} \mathrm{C}\right.$; 7 days). The acrylic plates were removed, the dentin surface was cleaned (PP or DE), and starch tubes were positioned on the dentin where the resin cements were applied. After $24 \mathrm{~h}$, the specimens were submitted to a microshear test (wire-loop method). Results: Twoway analysis of variance showed statistically significant influence of dentine surface treatments $(\mathrm{p}<0.001)$ and resin cement $(\mathrm{p}=0.001)$ in the bond strength values. The IDS/SBU+PP/U200 (7.24 MPa) and IDS/SBU+PP/ MULTI (6.40 MPa) groups presented higher values when compared to cleaning with DE (DE/U200=4.60 MPa; $\mathrm{DE} / \mathrm{MULTI}=1.45 \mathrm{MPa})$ and PP $(\mathrm{PP} / \mathrm{U} 200=3.74 \mathrm{MPa}$; PP/MULTI=3.14 MPa). Statistical difference was also found between the cements when dental excavator treatment was used (RelyX U200 > Multilink Automix). The IDS/SBU+PP protocol presented a higher percentage of cohesive failures. The micrographs showed differences in dentin surface characteristics among the groups. Conclusion: Immediate dentin sealing increased the bond strength of the resin cements to dentin compared to mechanical cleaning only, regardless the resin cement.
\end{abstract}

\section{KEYWORDS}

Cleaning; Dentin sealing; Provisional cement; Resin cement.

\section{RESUMO}

Objetivo: Avaliar a influência do selamento dentinário imediato (IDS) e dos métodos mecânicos de remoção do cimento provisório na resistência de união entre dentina e cimentos resinosos. Materiais e Métodos: Incisivos bovinos foram desgastados até a exposição da dentina e divididos de acordo com dois fatores: "tratamento da superfície dentinária" - limpeza com cureta dentária manual (DE), com escova de cerdas Robinson e pasta de pedra-pomes (PP) ou aplicação de IDS com Single Bond 2 (IDS/SB + PP) ou Single Bond Universal (IDS/SBU+PP) mais limpeza com PP; e "cimento resinoso" - autoadesivo (RelyX U200) ou cimento convencional com adesivo autocondicionante (Multilink Automix). Simulando a restauração provisória, placas de resina acrílica foram cimentadas na superfície dentinária (com ou sem IDS) com um cimento provisório sem eugenol e armazenadas em água destilada $\left(37^{\circ} \mathrm{C} ; 7\right.$ dias). As placas de acrílico foram removidas, a superfície dentinária foi limpa (PP ou $\mathrm{DE}$ ) e tubos de amido foram posicionados na dentina onde os cimentos resinosos foram aplicados. Após 24 h, os 
corpos-de-prova foram submetidos ao ensaio de microcisalhamento (método wire-loop). Resultados: A análise de variância de dois fatores mostrou influência estatisticamente significativa dos tratamentos de superfície dentinária $(\mathrm{p}<0,001)$ e cimento resinoso $(\mathrm{p}=0,001)$ nos valores de resistência de união. Os grupos IDS/SBU+PP/U200 (7,24 MPa) e IDS/SBU+PP/MULTI (6,40 MPa) apresentaram valores maiores quando comparados à limpeza com DE (DE/U200 = 4,60 MPa; DE/MULTI= 1,45 MPa) e PP (PP/U200= 3,74 MPa; PP/MULTI= 3,14 MPa). Uma diferença estatística também foi encontrada entre os cimentos quando o tratamento com cureta dentária foi usado (RelyX U200 > Multilink Automix). O protocolo IDS/SBU+PP apresentou maior percentual de falhas coesivas. As micrografias mostraram diferenças nas características da superfície dentinária entre os grupos. Conclusão: O selamento dentinário imediato aumentou a resistência de união dos cimentos resinosos à dentina em comparação com a limpeza mecânica apenas, independentemente do cimento resinoso.

\section{PALAVRAS-CHAVE}

Limpeza; Selamento de dentina; Cimento provisório; Cimento resinoso.

\section{INTRODUCTION}

Fixed prosthetic rehabilitation requires that the prepared teeth and the involved periodontal tissue should be prepared, conditioned and protected by the provisional restoration until the final restoration is installed. For this proposal, the temporary cements have an important function in retaining the provisional restoration. In this sense, the type of temporary cement and the method used for its removal may affect the adhesion of the resin composite cements to the dental substrate [1-3].

Among the alternatives for cleaning dental preparation, mechanical procedures stand out, such as nylon brushes coupled to rotary instruments (with or without the use of pumice paste or prophylactic paste, and at different rotations per minute), sandblasting (varying in pressure, distance, particles type and size), dental excavators and ultrasonic instruments [2,4-6]. On the other hand, there are chemical treatments (e.g., chlorhexidine gluconate, ethyl acetate and acetone) that only act superficially in cleaning, being less efficient in removing temporary cement residues $[7,8]$.

However, adhesion to dentin free of contaminants is not present in the conventional cementation technique because even if the clinicians are very careful at the time of dentin cleaning, it will be impossible to obtain the same surface from immediately after the tooth preparation [9]. Then, in this context, the immediate dentin sealing (IDS) can be indicated, which consists in a thin layer application of adhesive after preparation and prior to the temporary cementation. The IDS technique allows the preservation of fresh dentin in its ideal condition for adhesion and reduces postoperative problems associated with prepared teeth, such as dental sensitivity [10-13].
It is well known that IDS improve the adhesion with resin cements, the bonding reliability and durability, and, in some cases, the fracture strength of indirect restorations bonded to dentin [9,13-17]. Recently, the clinical benefit of IDS technique on survival rates was shown in a study on laminate veneers [11]. However, the literature still does not show sufficient scientific evidence on the best way of cleaning the temporary cement, which should also be clinically feasible, for strong adhesion to the self-adhesive resin cements and conventional resin cements with self-etching adhesive.

According to the technique, IDS can be performed with conventional etch-and-rinse and with self-etching adhesive systems [5]. The conventional system uses phosphoric acid etching prior to the adhesive application in order to demineralize the enamel and the dentin, and create a strong hybrid layer [18]. Self-etching adhesives contain acidic monomers capable of simultaneously etching and priming the surface of the dental substrates [19].

A dentin surface free of contaminants is even more important and critical when self-adhesive cements and self-etching adhesives are applied in final bonding, since they do not require dentin previous etching [20]. In such scenario, the conventional dentin treatment with phosphoric acid etching, which could better eliminate dentinal tubule residues, is contraindicated as these systems are independent of its use, i.e. the self-adhesive cement chemically interacts with the hydroxyapatite of the dentin and the selfetching system directly interact with the dentin smear layer to create a hybrid layer.

Considering the aforementioned subjects, this in vitro study investigated the influence of IDS and 
different methods for mechanically removing the temporary cement on the bond strength between the dentin and two resin cements. The following null hypotheses were tested: 1 ) dentin surface treatments would not affect the bond strength regardless the resin cements; and 2) there would be no difference between the conventional and the self-adhesive resin cements regardless the dentin surface treatment.

\section{MATERIALS AND METHODS}

\section{Study design}

The factors under study are "Dentin Surface Treatments" and "Resin Cements" (Table I). The main outcome analyzed was the bond strength through the microshear bond strength test ( $\mu$ SBS). The sample size calculation was based on an $80 \%$ statistical Power [21] assuming a standard deviation of 1.5 MPa with a detectable difference of 1.2 MPa based on Chaiyabutr and Kois [7], therefore the sample size was calculated at $\mathrm{n}=17$, and each resin cement cylinder was considered as a sample unit.

The materials used in this study are described in Table II.

\section{Specimens preparation}

Five healthy bovine teeth per experimental group were collected, cleaned and stored in distilled water $\left(4^{\circ} \mathrm{C}\right)$ for a maximum period of 3 months. The teeth's roots were then cut in the cement-enamel junction region with a doubleface diamond disc (7016 - KG Sorensen, Cotia, Brazil) under constant water cooling.

Table I - Experimental design

\begin{tabular}{|c|c|c|}
\hline Groups & $\begin{array}{l}\text { Dentin Surface } \\
\text { Treatments }\end{array}$ & $\begin{array}{l}\text { Resin } \\
\text { cements }\end{array}$ \\
\hline DE/U200 & \multirow{2}{*}{$\begin{array}{l}\text { Cleaning with dental } \\
\text { excavator (DE) }\end{array}$} & RelyX U200 \\
\hline DE/MULTI & & $\begin{array}{l}\text { Multilink } \\
\text { Automix }\end{array}$ \\
\hline $\mathrm{PP} / \mathrm{U} 200$ & \multirow{2}{*}{$\begin{array}{l}\text { Cleaning with Robinson } \\
\text { bristle brush and pumice } \\
\text { paste (PP) }\end{array}$} & RelyX U200 \\
\hline PP/MULTI & & $\begin{array}{l}\text { Multilink } \\
\text { Automix }\end{array}$ \\
\hline IDS/SB+PP/U200 & \multirow{2}{*}{$\begin{array}{l}\text { Immediate Dentin Sealing } \\
\text { (IDS) with Single } \\
\text { Bond } 2+\text { PP }\end{array}$} & RelyX U200 \\
\hline IDS/SB+PP/MULTI & & $\begin{array}{l}\text { Multilink } \\
\text { Automix }\end{array}$ \\
\hline IDS/SBU+PP/U200 & \multirow[b]{2}{*}{$\begin{array}{l}\text { IDS with Single Bond } \\
\text { Universal + PP }\end{array}$} & RelyX U200 \\
\hline IDS/SBU+PP/MULTI & & $\begin{array}{l}\text { Multilink } \\
\text { Automix }\end{array}$ \\
\hline
\end{tabular}

Table II - Materials, commercial name, manufacturer and chemical composition

\begin{tabular}{|c|c|c|}
\hline Material & $\begin{array}{l}\text { Commercial } \\
\text { name, } \\
\text { manufacturer }\end{array}$ & Composition* \\
\hline \multirow[t]{2}{*}{$\begin{array}{l}\text { Temporary } \\
\text { Cement }\end{array}$} & \multirow[t]{2}{*}{$\begin{array}{l}\text { Temp-Bond NE Kerr } \\
\text { Corporation, Orange, } \\
\text { USA }\end{array}$} & $\begin{array}{l}\text { Base paste: zinc } \\
\text { oxide, mineral oil, } \\
\text { lecithin, corn starch } \\
\text { and iron oxide } \\
\text { pigments. }\end{array}$ \\
\hline & & $\begin{array}{l}\text { Catalytic paste: } \\
\text { polyorganic acids. }\end{array}$ \\
\hline \multirow{2}{*}{$\begin{array}{l}\text { Self-adhesive } \\
\text { resin cement }\end{array}$} & \multirow{2}{*}{$\begin{array}{l}\text { RelyX U200, 3M } \\
\text { ESPE, St. Paul, USA }\end{array}$} & $\begin{array}{l}\text { Base paste: } \\
\text { methacrylate } \\
\text { monomers containing } \\
\text { phosphoric acid } \\
\text { groups, methacrylate } \\
\text { monomers, } \\
\text { initiators, stabilizers, } \\
\text { rheological additives. }\end{array}$ \\
\hline & & $\begin{array}{l}\text { Catalytic paste: } \\
\text { methacrylate } \\
\text { monomers, alkali } \\
\text { fillers, silanized fillers, } \\
\text { initiator components, } \\
\text { stabilizers, pigments, } \\
\text { rheological additives, } \\
\text { zirconia / silica fillers. }\end{array}$ \\
\hline $\begin{array}{l}\text { Conventional } \\
\text { resin cement }\end{array}$ & $\begin{array}{l}\text { Multilink Automix; } \\
\text { Ivoclar Vivadent } \\
\text { AG, Schaan, } \\
\text { Liechtenstein }\end{array}$ & $\begin{array}{l}\text { Dimethacrylate and } \\
\text { HEMA. Inorganic } \\
\text { particles include } \\
\text { barium glass, } \\
\text { ytterbium trifluoride } \\
\text { and mixed spheroidal } \\
\text { oxides. }\end{array}$ \\
\hline \multirow{2}{*}{$\begin{array}{l}\text { Self-etching } \\
\text { adhesive } \\
\text { system of the } \\
\text { conventional } \\
\text { resin cement }\end{array}$} & \multirow[b]{2}{*}{$\begin{array}{l}\text { Multilink Primer A } \\
\text { and Primer B }\end{array}$} & $\begin{array}{l}\text { Primer A: Aqueous } \\
\text { solution of primers. }\end{array}$ \\
\hline & & $\begin{array}{l}\text { Primer B: HEMA, } \\
\text { phosphonic acid } \\
\text { and methacrylate } \\
\text { monomers. }\end{array}$ \\
\hline $\begin{array}{l}\text { Two-step } \\
\text { adhesive system } \\
\text { (phosphoric } \\
\text { acid etching + } \\
\text { adhesive) }\end{array}$ & $\begin{array}{l}\text { Single Bond 2, } \\
3 M \text { ESPE }\end{array}$ & $\begin{array}{l}\text { Ethyl alcohol; Bis- } \\
\text { GMA; silane-treated } \\
\text { silica (nanoparticles); } \\
\text { HEMA; glycerol } \\
\text { 1,3-dimethacrylate; } \\
\text { copolymer of } \\
\text { acrylic and itaconic } \\
\text { acid; diurethane } \\
\text { dimethacrylate; } \\
\text { water. }\end{array}$ \\
\hline $\begin{array}{l}\text { Self-etching } \\
\text { adhesive system }\end{array}$ & $\begin{array}{l}\text { Single Bond } \\
\text { Universal, 3M ESPE }\end{array}$ & $\begin{array}{l}\text { Phosphated } \\
\text { monomers MDP, } \\
\text { dimethacrylate resins, } \\
\text { HEMA, Vitrebond } \\
\text { Copolymer, filler, } \\
\text { ethanol, water, } \\
\text { initiators, silane. }\end{array}$ \\
\hline Phosphoric acid & $\begin{array}{l}\text { Acid Gel 37\%, } \\
\text { Villevie; Joinville, } \\
\text { Brazil }\end{array}$ & $37 \%$ phosphoric acid. \\
\hline
\end{tabular}


In order to expose the dentin, the vestibular face of the teeth was ground with \#600-grit Silicon Carbide (SiC) paper (3M ESPE, St. Paul, USA) in a polishing machine (EcoMet/AutoMet 250, Buehler, Lake Bluff, IL, USA) under constant water cooling. The crowns were embedded in polyvinyl chloride (PVC) molds with a self-curing acrylic resin (VIPI Flash, Pirassununga, Brazil). To do so, doublesided tape (3M, Brazil, Sumaré, Brazil) was glued on a flat base, the crowns were placed on the tape with the vestibular face facing down in contact with the tape, and the PVC molds were positioned over the crowns. The acrylic resin was flowed into the mold and the teeth were stored again in distilled water $\left(4^{\circ} \mathrm{C}\right)$ after the resin final curing. The specimens were ground again (\#600-grit SiC paper as previously described) in order to remove the remaining glue from the double-sided tape, and then vigorously rinsed with air/water spray.

The specimens were randomly [22] distributed into 8 groups according to experimental design (Table I).

\section{Immediate Dentin Sealing (IDS)}

IDS was performed using two adhesive systems, namely the Single Bond 2 (SB - 3M ESPE, St. Paul, USA) and the Single Bond Universal (SBU - 3M ESPE). Both adhesive systems were handled and applied according to the manufacturers' recommendations.

The SB system requires a previous phosphoric acid etching step. Thus, the dentin was conditioned with $37 \%$ phosphoric acid (Acid Gel 37\%, Villevie, Joinville, Brazil) for 15 s, rinsed for $15 \mathrm{~s}$ and gently dried with the absorbent paper to keep it moist enough. Two layers of adhesive were then actively applied for $15 \mathrm{~s}$ using a disposable micro applicator (KG Sorensen, Cotia, Brazil), a gentle air spray was used to remove the excess and evaporate the solvent of the adhesive, and light curing (1200 mW/ $\mathrm{cm}^{2}$, Radii Cal, SDI, Bayswater, Australia) was carried out for $10 \mathrm{~s}$. For the SBU, a disposable micro applicator (KG Sorensen) was used for $20 \mathrm{~s}$ for active application of the adhesive to the dentin surface. Then, a gentle air spray was applied to remove the excess and evaporate the solvent from the adhesive, and finally light cured (Radii Cal, SDI) for $10 \mathrm{~s}$.

\section{Temporary cementation}

To simulate the temporary restoration, selfcured acrylic resin (VIPI Flash, Pirassununga,
Brazil) plates $\left(12 \times 6 \times 2 \mathrm{~mm}^{3}\right)$ were cemented with a non-eugenol temporary cement (TempBond NE Kerr Corporation, Orange, USA) on the dentin surface, with a constant load of $500 \mathrm{~g}$ until the final curing of the temporary cement (5 min). The specimens were subsequently stored in distilled water for 7 days in a laboratory steam chamber at $37{ }^{\circ} \mathrm{C}\left( \pm 2{ }^{\circ} \mathrm{C}\right)$ (Laboratory Thermo incubator, FANEM, São Paulo, Brazil). After this, the resin plates were removed and the dentin was submitted to the different cleaning protocols.

\section{Cleaning protocols}

The temporary cement was removed according to the following treatments:

$P P$ : Cleaning with pumice paste using Robinson bristle brushes (Microdont, São Paulo, Brazil) coupled to a low-speed motor at $5,000 \mathrm{rpm}$, applying light and constant pressure and with circular movements for $15 \mathrm{~s}$.

$D E$ : Cleaning with a manual dental excavator (no. 17/18 long, Quinelato, Rio Claro, Brazil) until complete removal of the temporary cement, according to visual inspection.

\section{Definitive cementation}

Two resin cements, one self-adhesive (U200 - RelyX U200) and one conventional with selfetching adhesive (MULTI - Multilink Automix), were used for the final cementation step.

After cleaning the dentin surface, three starch tubes (Renata, Pastifício Selmi, Londrina, Brazil) with approximately $1 \mathrm{~mm}$ of height and $0.96 \mathrm{~mm}$ of internal diameter per tooth were positioned over the dentin surface and fixed with wax number 7 (Lysanda, São Paulo, Brazil). For the conventional cement (Multilink Automix) prior to fixation of the starch tubes, the Primers A and B were mixed and applied with a micro applicator (KG Sorensen) for $30 \mathrm{~s}$ on the dentin surface and the excess was removed with gentle air-spray.

Each resin cement was manipulated according to the manufacturer's recommendations and inserted into the starch matrices with an exploratory dental tool (17S - 23S, GolgranMillennium; São Caetano do Sul, Brazil). The cement excesses in the upper part of the starch matrix were carefully removed with a dental spatula (Titanium Spatula no. 9, GolgranMillennium) and both cements were light-cured (Radii Cal, SDI) for $20 \mathrm{~s}$ for each specimen. 
After, the specimens were stored in distilled water in an oven at $37^{\circ} \mathrm{C}\left( \pm 2{ }^{\circ} \mathrm{C}\right)$ (Laboratory Thermo incubator - FANEM) for $24 \mathrm{~h}$ so that the starch tube decomposed and was easily removed without generating stress on the specimens.

\section{Microshear bond strength ( $\mu$ SBS) test}

Prior to the mechanical test, the specimens (resin cement cylinders) were individually inspected under an optical microscope (Stereo Discovery V20, Carl Zeiss, Gottingen, Germany) at $40 \times$ of magnification to identify any failure (e.g., bubbles, porosity) at the adhesive interface. The specimen was discarded and replaced if irregularities were found. The embedded tooth was mounted in a jig attached to a universal testing machine (EMIC DL-2000, São José dos Pinhais, Brazil) and the test was performed using the wire-loop method (stainless steel wire; $\varnothing=20 \mu \mathrm{m}$ ). The wire was looped around the cylinder, parallel to and as close as possible to the cement-dentin interface, and a constant load at a cross-head speed of $1.0 \mathrm{~mm} / \mathrm{min}$ was applied until failure occurred. The load at failure values obtained in Newton $(\mathrm{N})$ were recorded and the bond strength in Megapascal ( $\mathrm{MPa}$ ) was calculated dividing the shear load in $\mathrm{N}$ by the surface area of the specimen at the adhesive interface $\left(0.72 \mathrm{~mm}^{2}\right)$.

\section{Failure mode analysis}

The bonding interfaces were observed with a stereomicroscope (Stereo Discovery V20, Carl Zeiss; Gottingen, Germany) at $40 \times$ of magnification to distinguish the failure mode. The failures were classified as Adhesive (adhesive failure between dentin and cement) or Cohesive (cohesive failure of the cement).

\section{Microscopic analysis}

Topographic and cross-section microscopic analyses of the dentin was performed using scanning electron microscopy (SEM - Vega3, Tescan, Czech Republic) in representative specimens for different conditions $(n=1)$. Topographic analysis was carried out after IDS and cleaning treatments and in two additional conditions: a phosphoric acid etched (37\% for $15 \mathrm{~s})$ dentin and a control group where the smear layer was created ( $\mathrm{SiC}$ paper \#600-grit size) in the dentin. The specimens were dehydrated in an ascending series of ethanol (25\% for $5 \mathrm{~min}$,
$50 \%$ for $5 \mathrm{~min}, 75 \%$ for $30 \mathrm{~min}$, and $100 \%$ for $3 \mathrm{~h}$ ) and then additionally dried in a desiccator for $24 \mathrm{~h}$ prior to gold-sputtering and final analysis at $7,500 \times$ of magnification. For the cross-section view, the four dentin surface conditions under study and four additional samples [control ( $\mathrm{SiC}$ paper \#600 - smear layer), dirty control (smear layer + temporary cement not cleaned), just immediate dentin sealing with Single Bond 2, and just immediate dentin sealing with Single Bond Universal] were analyzed at $1,500 \times$ and $7,000 \times$ of magnification. The specimens were chemically fixed by immersion in $2.5 \%$ glutaraldehyde in $0.1 \mathrm{M}$ sodium cacodylate buffer for $6 \mathrm{~h}$, then dehydrated in an ascending series of ethanol (25\% for $15 \mathrm{~min}, 50 \%$ for $15 \mathrm{~min}, 75 \%$ for $15 \mathrm{~min}$ and $100 \%$ for $3 \mathrm{~h}$ ) prior to gold-sputtering and SEM analysis.

\section{Statistical analysis}

The bond strength values were calculated in $\mathrm{MPa}$, the data were submitted to logarithmic transformation and the normality (ShapiroWilk test) and homoscedasticity (Levene test, $\mathrm{p}=0.306)$ tests were performed. Two-way analysis of variance (Two-way ANOVA) and post-hoc Tukey tests $(\alpha=0.05)$ were carried out to compare the microshear bond strength values between groups. The statistical analyses were performed using a statistical software (Statistix 8.0 for Windows, Analytical Software Inc, Tallahassee, FL, USA).

\section{RESULTS}

Two-way analysis of variance showed statistically significant impact of the 'dentin surface treatment' $(\mathrm{p}<0.001)$ and 'resin cement' $(\mathrm{p}=0.001)$ in the $\mu$ SBS results, but not for their interaction ('dentin surface treatment $\times$ resin cement', $\mathrm{p}=0.31$ ).

Comparing each cement separately, the IDS/SBU + PP dentin surface treatment created statistically higher bond strength results in both cements, being statistically similar to the group IDS/SB + PP. For the U200 cement, the group IDS/SB + PP was similar to PP and DE and for the MULTI cement the group IDS/SB+PP was similar to PP and higher than DE. In both cements, the PP and DE groups were statistically similar between them (Table III). 
Table III - Microshear bond strength test, mean and standard deviation (SD)

\begin{tabular}{lcc} 
Dentin Surface & \multicolumn{2}{c}{ Resin Cements } \\
Treatments & $\begin{array}{c}\text { RelyX U200 } \\
\text { Mean (SD) - MPa }\end{array}$ & $\begin{array}{c}\text { Multilink Automix } \\
\text { Mean (SD) - MPa }\end{array}$ \\
\hline DE & $4.60(2.3)^{\mathrm{Ba}}$ & $1.45(0.8)^{\mathrm{Cb}}$ \\
\hline PP & $3.74(2.1)^{\mathrm{Ba}}$ & $3.14(2.6)^{\mathrm{BCa}}$ \\
IDS/SB+PP & $5.90(4.0)^{\mathrm{ABa}}$ & $3.93(2.0)^{\mathrm{Aba}}$ \\
IDS/SBU+PP & $7.24(2.9)^{\mathrm{Aa}}$ & $6.40(3.75)^{\mathrm{Aa}}$ \\
\hline
\end{tabular}

Different uppercase letters in each column and different lowercase letters in each row represent significant statistical difference (Twoway ANOVA and post-hoc Tukey tests, $\alpha=0.05$ ).
Comparing each dentin surface treatment between the cements, all behaved statistically similar, except the DE group that performed better when the U200 cement was applied (DE/ U200 > DE/MULTI) (Table III).

The predominant failure mode was the adhesive failure at the dentin/cement interface (Figures 1 and 2A), except for the IDS/SBU+PP group which had a higher percentage of cohesive failure for both cements (Figures 1 and 2B).

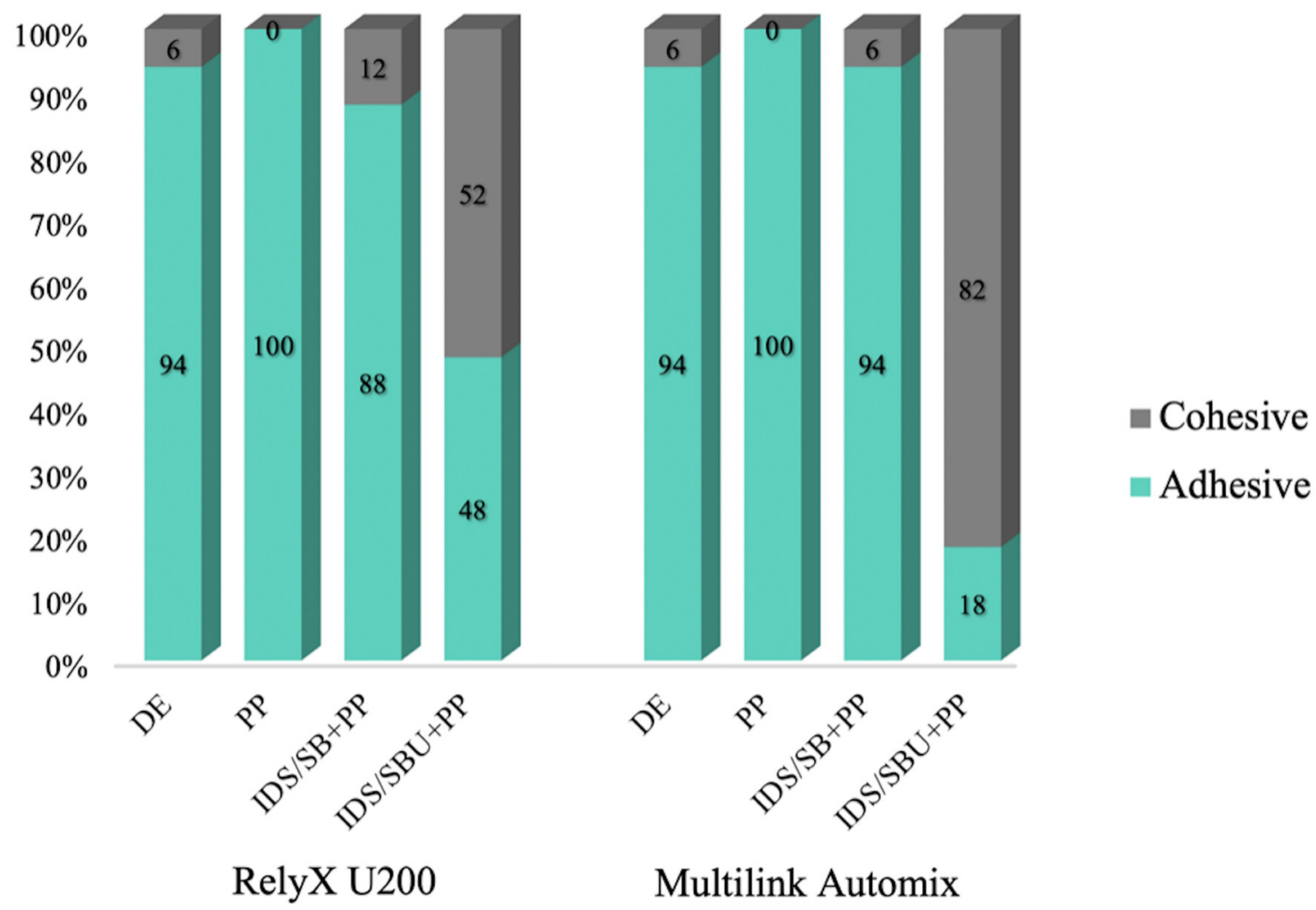

Figure 1 - Percentage of failure mode for each experimental group. Adhesive: failure at the dentine/cement interface; Cohesive: cohesive failure of resin cement.

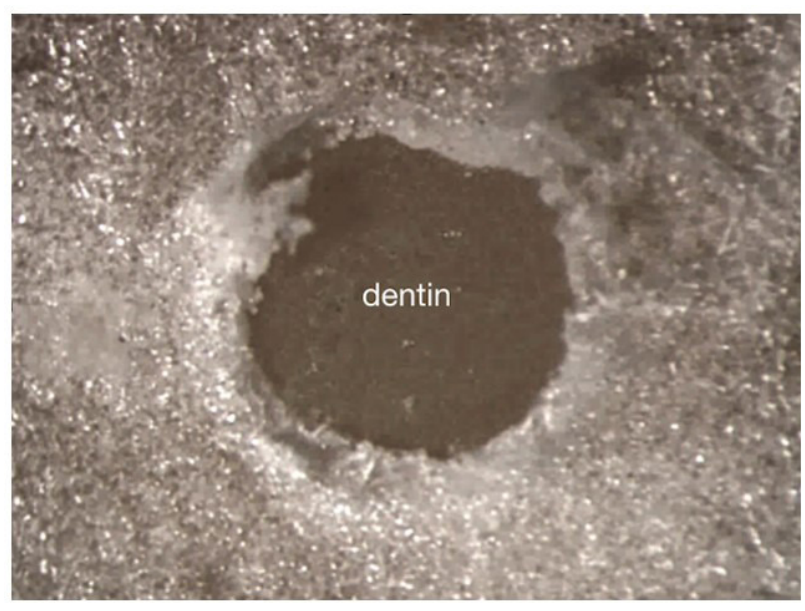

A

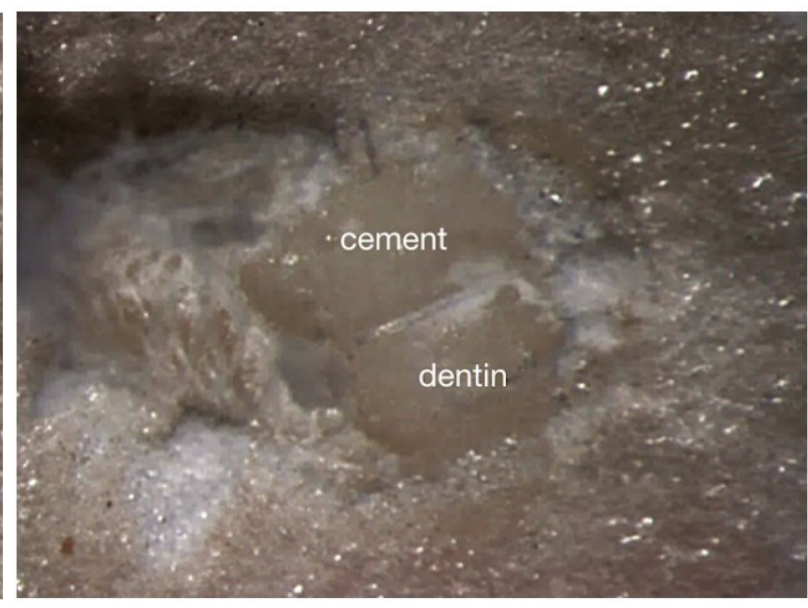

B

Figure 2 - Failure modes during the microshear bond strength test. A) Adhesive failure and B) Cohesive failure. 
The topographic analysis showed that the DE protocol seems inefficient for completely removing the temporary cement remnants and left the same aspect of the smear layer control group (Figure $3 \mathrm{~B}$ and $3 \mathrm{C}$ ). The PP treatment provided better dentin exposure, removing the smear layer and exposing some dentinal tubules (Figure 3D). The PP step in the IDS/SB group removed all the adhesive layer from the dentin surface, but the SB still remained inside the dentinal tubules, obliterating them (Figure 3E). Regarding the IDS with the SBU group, cleaning with PP was not capable of exposing the dentin and the IDS layer remained quite untouched (Figure 3F).

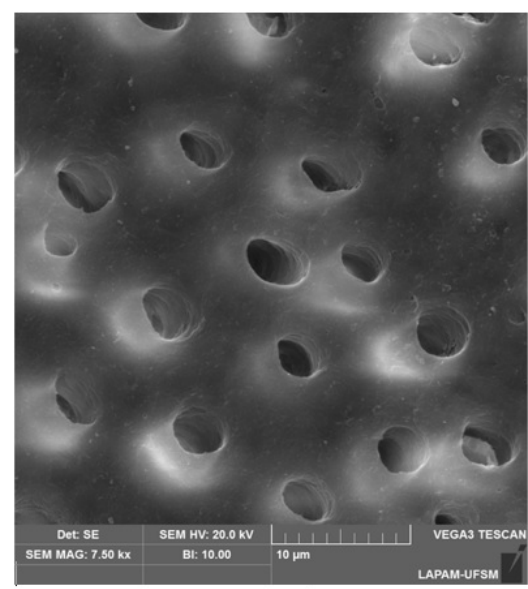

A

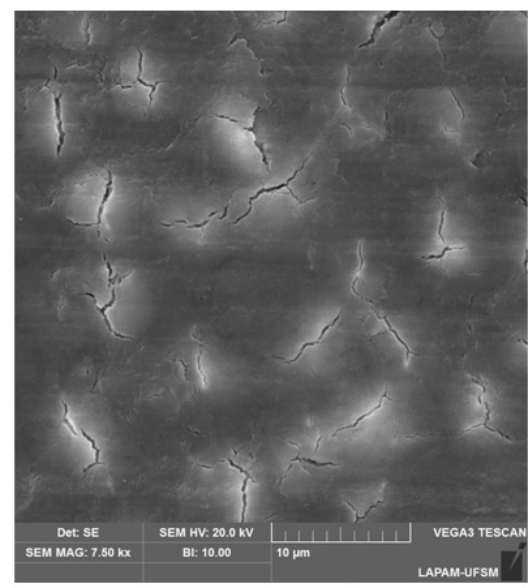

C

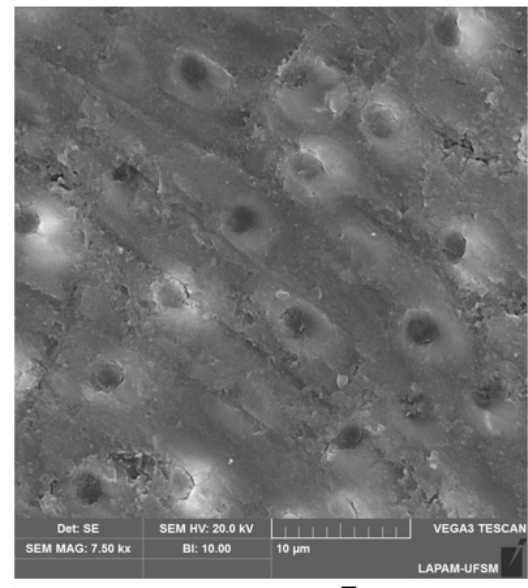

E

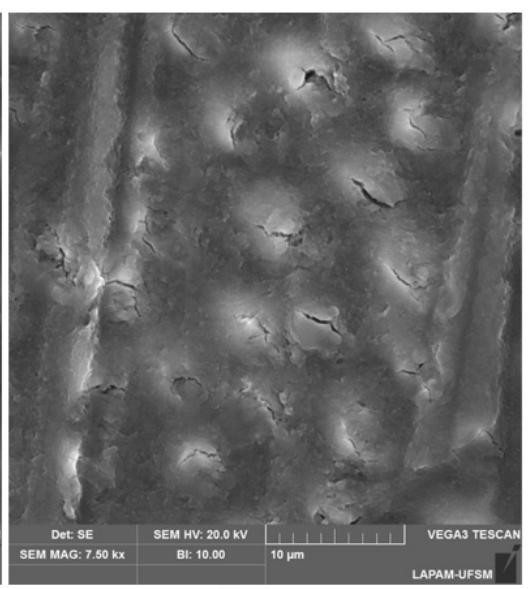

B

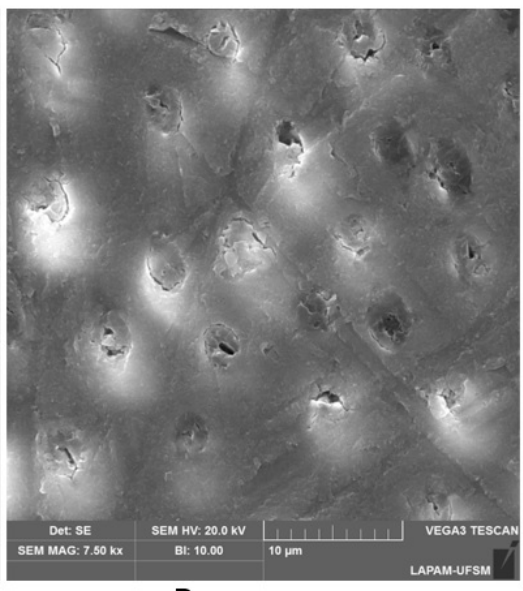

D

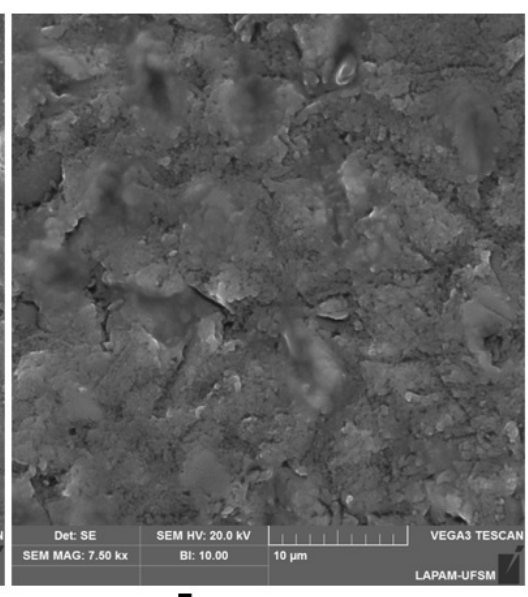

$\mathbf{F}$

Figure 3 - SEM micrographs (7,500x of magnification) of the dentin surface prior to temporary cementation and after surface treatments. A (CA): $37 \%$ phosphoric acid etching for 15 s; B (C): control (SiC paper \#600 - smear layer); C (DE): cleaning with a dental excavator after temporary cementation; $\mathrm{D}(\mathrm{PP})$ : cleaning with pumice paste and Robinson bristle brush after temporary cementation; E (IDS/SB+PP): immediate dentin sealing with Single Bond 2 + temporary cementation + PP cleaning; and F (IDS/SBU+PP): immediate dentin sealing with Single Bond Universal + temporary cementation + PP cleaning. 
In the cross-sectional micrographs, the perception that DE is less efficient in cleaning the dentin surface is clearly corroborated by the presence of remnants inside the dentinal tubules (Figure 4C; white dashed arrows). This view also corroborates the aspect found for the IDS groups in the topographical analysis, where the IDS with SB system is completely removed by the PP cleaning protocol from the dentin surface (Figure 4G) and the IDS with SBU remains quite untouched (Figure 4H).
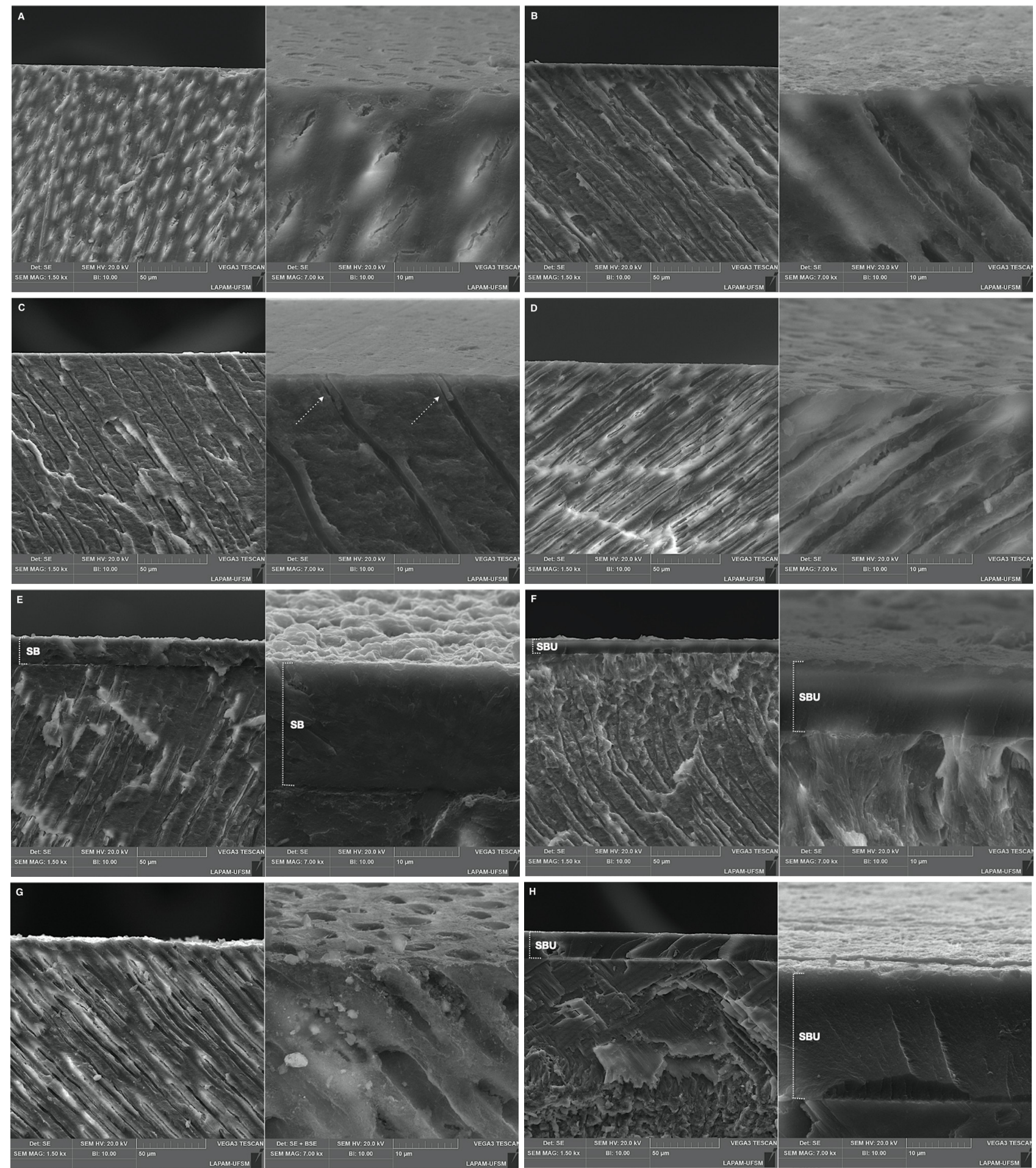

Figure 4 - SEM micrographs of dentin cross-sections in 1,500x and 7,000x of magnification. A (C): control (only smear layer without temporary cementation); B (DC): Dirty control (smear layer + temporary cement); C (DE): cleaning with dental excavator after temporary cementation; $\mathrm{D}(\mathrm{PP})$ : cleaning with pumice paste and Robinson bristle brush after temporary cementation; $\mathrm{E}$ (SB): immediate dentin sealing with Single Bond 2; F (SBU): immediate dentin sealing with Single Bond Universal; G (IDS/SB+PP): IDS with Single Bond 2 + temporary cementation + PP cleaning; H (IDS/SBU+PP): IDS with Single Bond Universal+ temporary cementation + PP cleaning. 


\section{DISCUSSION}

The results of our study showed that the bond strength was influenced by the dentin surface treatments and type of resin cement applied. The immediate dentin sealing (IDS) proved to be an important step in increasing the bond strength between resin cements and dentin. So, the fresh/as-prepared dentin should be protected before temporary cementation for a better bond strength to self-adhesive and conventional resin cements in the final adhesive bonding step.

The first null hypothesis of the present study was rejected since the dentin surface treatments influenced the microshear bond strength ( $\mu$ SBS) results. The IDS/SBU+PP group provided the highest $\mu$ SBS values, and was statistically similar to IDS/SB + PP for both cements. The DE group resulted in lower $\mu$ SBS values, but statistically similar to PP for the conventional resin cement. The lower $\mu$ SBS values for the DE group confirm the findings by Chaiyabutr and Kois [7], who found in the microscopic analysis residual particles of temporary cement at the dentin surface after cleaning with a hand instrument. This may justify the lowest $\mu$ SBS values in the present study for both DE and PP groups, as temporary cement remnants may have compromised the interactions between resin cement and dentin. In addition, the micrographs also show a greater obliteration of the dentin tubules for the DE group (Figures $3 \mathrm{C}$ and $4 \mathrm{C}$ ) in relation to the control (Figures 3B and 4A). However, the surface treatment using pumice paste with Robinson bristle brush (Figures 3D and 4D) seems to have better cleaning ability compared to the dental excavator (Figures 3C and 4C) but still resulting in a shallow effect with limited exposure of the dentinal tubules. The tubules in DE and PP groups appear to be equally obliterated, which may explain their similar bond strength values for both cements (Table III). The obliteration of dentinal tubules prevents adhesive tags from being formed, decreasing adhesion [23].

Regarding the IDS application, the IDS/ SBU + PP groups (for both resin cements) presented statistically higher values of $\mu$ SBS than the PP and DE groups. That is corroborated by previous studies where the IDS provided higher bond strength values compared to its non-application $[9,14]$. On the other hand, the micrograph images showed that in the SB system the adhesive layer was completely removed after cleaning with PP (Figures 4E and 4G), while with SBU the adhesive layer was maintained untouched (Figures 4F and 4H). In fact, in indirect restorations the adhesive layer appears to be the most fragile component of the dentin-cement interface [14]. Thus, applying an adhesive layer after the tooth preparation and preceding the temporary cementation promotes an increase in bond strength, since the dentin structure is more opened and free of contaminants [24], and the adhesive is allowed to completely polymerize during the waiting time (prior to the final cementation). In addition, this adhesive layer protects the dentinal tissue and reduces dentin sensitivity, resulting in greater comfort for the patient and a better prognosis [25]. Sailer et al. [26], concluded that dentin sealing with a selfetching adhesive (Clearfil SE Bond) improved the bond strength of the self-adhesive resin cement (RelyX Unicem), corroborating our findings.

The bond strength of the self-adhesive cement to the dentin was higher than that of the conventional cement when the dental excavator was used to clean the dentin, so the second null hypothesis was rejected (Table III). Two types of resin cements were used in the present study, a conventional cement with self-etching adhesive and a self-adhesive. In the first one, a selfetching primer with acid monomers demineralize the tooth structure as soon as they come in contact with it, disorganizing the smear layer and incorporating it into the hybrid layer [27]. Unlike the conventional cement with self-etching adhesive, the self-adhesive resin cements bond to the dentin through a chemical process in which the acidic monomers of the cement interact with the calcium ions of tooth, creating a stable bond through the chelation between the methacrylate network and the dental structure [28]. Moreover, micromechanical retention occurs due to the action of acidic monomers groups that cause slight smear layer demineralization, superficially infiltrating the dentin $[29,30]$. In this sense, cleaning with DE provided worse bonding resistance results when applying conventional cement with self-etching adhesive than selfadhesive (Table III), which can be explained by its different mechanisms of action.

Finally, the main limitation of the present study was the high percentage of cohesive failures in the IDS groups (Figure 1). Braga et al. [31], reported that cohesive failures are explained by 
the test mechanics and fragility of the materials involved. One of the reasons for cohesive failures could be the displacement of the stainless-steel wire to a position further from the adhesive interface during the microshear test [31], but this assumption is refuted since this failure mode was only predominant in one tested group, excluding a possible technical error. Therefore, the possible explanation would be that the bond strength between the Single Bond Universal and the cements was higher than the intrinsic resistance of both resin cements used [31]. Therefore, the analysis of the data should be used with caution.

Another limitation of this in vitro study was the absence of adhesive interface aging (storage and/or thermocycling). Therefore, studies using different cements and surface treatments and applying aging protocols would corroborate the findings of the present study. In addition, clinical studies addressing this subject are widely encouraged.

\section{CONCLUSION}

Based on the findings of this in vitro study, we may conclude that the immediate dentin sealing with the SBU system prior to the temporary cementation provided better bond strength results for both resin cements than only cleaning the dentin with dental excavator or pumice paste; and that the self-adhesive (RelyX U200) resin cement produced better results than the conventional cement with self-etching adhesive (Multilink Automix) for the dentin surface cleaned with the dental excavator.

\section{Acknowledgments}

The authors declare no conflict of interests. This study was partly financed by the Brazilian Federal Agency for Coordination of Improvement of Higher Education Personnel (CAPES) (Finance code 001). We especially thank Ivoclar Vivadent for donating some materials, and finally we emphasize that those institutions had no role in the study design, data collection or analysis, decision to publish or in preparing the manuscript.

\section{Conflict of Interest}

The authors declare there is no conflict of interest.

\section{Funding}

This research did not receive any specific grant from funding agencies in the public, commercial, or not-for-profit sectors.

\section{Regulatory Statement}

The authors declare that this in vitro study did not require application to the institution's ethics committee.

\section{REFERENCES}

1. Fonseca RB, Martins LR, Quagliatto PS, Soares CJ. Influence of provisional cements on ultimate bond strength of indirect composite restorations to dentin. J Adhes Dent. 2005;7(3):22530. PMid:16240963.

2. Tajiri-Yamada $Y$, Mine A, Nakatani $H$, Kawaguchi-Uemura A, Matsumoto $M$, Hagino $R$, et al. MDP is effective for removing residual polycarboxylate temporary cement as an adhesion inhibitor. Dent Mater J. 2020;39(6):1087-95. http://dx.doi. org/10.4012/dmj.2020-132. PMid:32999261.

3. Zaniboni JF, Silva AM, Fernández E, Melo Alencar C, Morais JMP, Campos EA, et al. Temporary cement residues affect the bond strength and dentin penetration of self-adhesive resin cement in fiberglass post cementation. Microsc Res Tech. 2021;84(10):235160. http://dx.doi.org/10.1002/jemt.23789. PMid:33960585.

4. Kanakuri K, Kawamoto $Y$, Matsumura H. Influence of temporary cement remnant and surface cleaning method on bond strength to dentin of a composite luting system. J Oral Sci. 2005;47(1):913. http://dx.doi.org/10.2334/josnusd.47.9. PMid:15881223.

5. Özcan M, Lamperti S. Effect of mechanical and air-particle cleansing protocols of provisional cement on immediate dentin sealing layer and subsequent adhesion of resin composite cement. J Adhes Sci Technol. 2015;29(24):2731-43. http://dx.doi. org/10.1080/01694243.2015.1087254.

6. AlZain S, Kattadiyil MT, AlHelal A, Alqahtani A. Effect of intraoral mechanical cleaning techniques on bond strength of cast crowns to metal cores. J Prosthodont. 2020;29(1):69-73. http://dx.doi. org/10.1111/jopr.12721. PMid:29194830.

7. Chaiyabutr $Y$, Kois JC. The effects of tooth preparation cleansing protocols on the bond strength of self-adhesive resin luting cement to contaminated dentin. Oper Dent. 2008;33(5):556-63. http://dx.doi.org/10.2341/07-141. PMid:18833862.

8. Santos MJ, Bapoo H, Rizkalla AS, Santos GC Jr, Riskalla AS, Santos GC. Effect of dentin-cleaning techniques on the shear bond strength of self-adhesive resin luting cement to dentin. Oper Dent. 2011;36(5):512-20. http://dx.doi.org/10.2341/10392-L. PMid:21834711.

9. Magne P. Immediate dentin sealing: a fundamental procedure for indirect bonded restoration. J Esthet Restor Dent. 2005;17(3):14454, discussion 155. http://dx.doi.org/10.1111/j.1708-8240.2005 tb00103.x. PMid:15996383.

10. Qanungo A, Aras MA, Chitre V, Mysore A, Amin B, Daswani SR. Immediate dentin sealing for indirect bonded restorations. J Prosthodont Res. 2016;60(4):240-9. http://dx.doi.org/10.1016/j. jpor.2016.04.001. PMid:27131858.

11. Gresnigt MMM, Cune MS, Schuitemaker J, van der Made SAM, Meisberger EW, Magne P, et al. Performance of ceramic laminate veneers with immediate dentine sealing: An 11 year prospective clinical trial. Dent Mater. 2019;35(7):1042-52. http://dx.doi. org/10.1016/j.dental.2019.04.008. PMid:31084936. 
12. van den Breemer C, Gresnigt M, Özcan M, Kerdijk W, Cune MS Prospective randomized clinical trial on the survival of lithium disilicate posterior partial crowns bonded using immediate or delayed dentin sealing: short-term results on tooth sensitivity and patient satisfaction. Oper Dent. 2019;44(5):E212-22. http:// dx.doi.org/10.2341/18-047-C. PMid:31461393.

13. van den Breemer CR, Özcan M, Pols MR, Postema AR, Cune MS, Gresnigt MM. Adhesion of resin cement to dentin: effects of adhesive promoters, immediate dentin sealing strategies, and surface conditioning. Int J Esthet Dent. 2019:14(1):52-63. PMid:30714054.

14. Magne P, So WS, Cascione D. Immediate dentin sealing supports delayed restoration placement. J Prosthet Dent. 2007;98(3):16674. http://dx.doi.org/10.1016/S0022-3913(07)60052-3. PMid:17854617.

15. Gresnigt MM, Cune MS, de Roos JG, Özcan M. Effect of immediate and delayed dentin sealing on the fracture strength, failure type and Weilbull characteristics of lithium disilicate laminate veneers. Dent Mater. 2016;32(4):e73-81. http://dx.doi. org/10.1016/j.dental.2016.01.001. PMid:26856454.

16. Murata T, Maseki T, Nara Y. Effect of immediate dentin sealing applications on bonding of CAD/CAM ceramic onlay restoration. Dent Mater J. 2018;37(6):928-39. http://dx.doi.org/10.4012/ dmj.2017-377. PMid:29998944.

17. Hofsteenge JW, Hogeveen F, Cune MS, Gresnigt MMM. Effect of immediate dentine sealing on the aging and fracture strength of lithium disilicate inlays and overlays. J Mech Behav Biomed Mater. 2020;110:103906. http://dx.doi.org/10.1016/j. jmbbm.2020.103906. PMid:32957211.

18. Van Meerbeek B, De Munck J, Yoshida Y, Inoue S, Vargas M, Vijay $P$, et al. Buonocore memorial lecture. Adhesion to enamel and dentin: current status and future challenges. Oper Dent. 2003;28(3):215-35. PMid:12760693.

19. Perdigão J. New developments in dental adhesion. Dent Clin North Am. 2007;51(2):333-57, viii. http://dx.doi.org/10.1016/j. cden.2007.01.001. PMid:17532916.

20. Burgess JO, Ghuman T, Cakir D, Swift EJ Jr. Self-adhesive resin cements. J Esthet Restor Dent. 2010;22(6):412-9. http://dx.doi. org/10.1111/j.1708-8240.2010.00378.x. PMid:21171499.
21. University of lowa. Java applets for power and sample size [Internet]. lowa: University of lowa; 2018 [cited 2021 Dec 1]. Available from: http://homepage.stat.uiowa.edu/ rlenth/Power

22. Random.org. What's this fuss about true randomness? [Internet] [cited 2021 Dec 1]. Available from: https://www.random.org

23. Perdigão J. Dentin bonding-variables related to the clinical situation and the substrate treatment. Dent Mater. 2010;26(2):e24-37. http://dx.doi.org/10.1016/j.dental.2009.11.149. PMid:20005565.

24. Paul SJ, Scharer P. Effect of provisional cements on the bond strength of various adhesive bonding systems on dentine. J Oral Rehabil. 1997;24(1):8-14. http://dx.doi.org/10.1046/j.13652842.1997.00484.x. PMid:9049913.

25. Holderegger C, Sailer I, Schuhmacher C, Schläpfer R, Hämmerle C, Fischer J. Shear bond strength of resin cements to human dentin. Dent Mater. 2008;24(7):944-50. http://dx. doi. org/10.1016/j.dental.2007.11.021. PMid:18190957.

26. Sailer I, Oendra AE, Stawarczyk B, Hämmerle CH. The effects of desensitizing resin, resin sealing, and provisional cement on the bond strength of dentin luted with self-adhesive and conventional resin cements. J Prosthet Dent. 2012;107(4):252-60. http://dx.doi. org/10.1016/S0022-3913(12)60070-5. PMid:22475468.

27. Knobloch LA, Gailey D, Azer S, Johnston WM, Clelland N, Kerby RE. Bond strengths of one- and two-step self-etch adhesive systems. J Prosthet Dent. 2007;97(4):216-22. http://dx.doi. org/10.1016/j.prosdent.2007.02.013. PMid:17499091.

28. Ferracane JL, Stansbury JW, Burke FJ. Self-adhesive resin cements - chemistry, properties and clinical considerations. J Oral Rehabil. 2011;38(4):295-314. http://dx.doi.org/10.1111/ j.1365-2842.2010.02148.x. PMid:21133983.

29. Bitter K, Paris S, Pfuertner C, Neumann K, Kielbassa AM Morphological and bond strength evaluation of different resin cements to root dentin. Eur J Oral Sci. 2009;117(3):326-33. http:// dx.doi.org/10.1111/j.1600-0722.2009.00623.x. PMid:19583763.

30. Gerth HU, Dammaschke T, Zuchner H, Schafer E. Chemical analysis and bonding reaction of RelyX Unicem and Bifix composites - a comparative study. Dent Mater. 2006;22(10):934-41. http:// dx.doi.org/10.1016/j.dental.2005.10.004. PMid:16364427.

31. Braga RR, Meira JB, Boaro LC, Xavier TA. Adhesion to tooth structure: a critical review of "macro" test methods. Dent Mater. 2010;26(2):e38-49. http://dx.doi.org/10.1016/j. dental.2009.11.150. PMid:20004960.

\section{Marília Pivetta Rippe}

(Corresponding address)

Universidade Federal de Santa Maria, Department of Restorative Dentistry, Santa

Maria, RS, Brazil.

Email: mariliarip@hotmail.com

Date submitted: 2021 March 13

Accepted submission: 2021 June 15 